821.161.1.08-32 Гогољ Н. В.

257.7

$398.3 / .4(=163)$

https://doi.org/10.18485/sj.2018.23.1.17

МИЛЕНА Б. МАРОЈЕВИЪ

Универзитет Источно Сарајево

Филозофски факултет Пале
Оригинални научни рад

Примљен: 04. 01. 2018.

Прихваћен: 29. 01. 2018.

\title{
МИТОЛОГЕМЕ У СТВАРАЛАЧКОМ ОПУСУ \\ Н. В. ГОГОљА
}

\begin{abstract}
У раду се анализирају митологеме источнословенске митологије у раном стваралаштву Н. В. Гогоља Вечери на салашу крај Дикањке. Поменуте митологеме су из сфере „доње митологије”. Сходно циљу истраживања утврђено је значење термина мит, митологија; маркиране су митологеме у збирци и извршена анализа концепата речи-лексама ведьма и черт методом митолошког архетипа.
\end{abstract}

Кључне речи: мит, митологија, словенска митологија, митологема, пандемонијум, Гогољ

\section{УВОД}

Паганство као древна религија Словена садржало је, осим аниматских, такође и анимичка веровања у споју са веровањем о трансцендентности душе и о способности натприродних сила ка различитим метаморфозама. После примања хришћанства натприродне силе су добиле назив „нечистих”, а имале су зооморфни, антропоморфни или мешовит облик. Према убеђењу старих Словена-пагана те силе су насељавале читаву васиону, која је била опасна, мада није увек доводила до нечег трагичног. Према народној фолклорној представи, на небу су се налазиле небеске силе, праведне и божије, док су

"milos@mail.ru 
пакао, подземни свет, мочваре, јаме и јаруге биле испуњене нечистим и тамним силама. Земља је била место борбе двају светова, а човек и његова душа су били центар те борбе.

\section{Паганство старих Словена}

Древна религија Словена било је паганство, незнабоштво (рус. язычество) и оно је обухватало како укупну духовну културу, тако и већи део материјалне. То значи да су припадници дате културе у свести имали уверење о сталном присуству и учешћу виших сила у свим делатностима и процесима рада. Главна идеја паганства изникла је из самог живота, те је оно обухватало погледе и живот људи старога света. Поред тога, реч ,језик” за старе Словене значила је исто што и „народ”, „етнос”. А у томе је садржана суштина веровања: оно је било народно, етничко, насупрот надетничким (светским) религијама.

Митолошке представе старих Словена су прави извор народне мудрости. То су и представе о земљи и космосу, о природи и њеним законима, о животу птица и животиња, о човековој судбини, домаћем огњишту, о његовој организацији и украсима, о предметима у домаћинству и одећи и свему осталом што представља дневни живот.

У СУ мит (од грчког mýthos) објашњава се као легенда, предање, као саставни део религиозног веровања (СУ 1996: том 2, 228). Митологија се тумачи као укупност, систем митова (Ибид.), док је митологема саставни елеменат митолошког сижеа.

\section{Митологија Словена}

Веровање у духове и демоне који испуњавају природу и непосредно утичу на човеков живот задржало се као реална религиозна свест све до савременог стања и није претрпело неке битније промене у дужем временском периоду.

У словенској демонологији може се издвојити неколико основних група које су постојале и у најранијој фази развоја друштва. Основу митолошког система чине ликови који воде порекло од разних врста покојника.

Огромну групу представљају демони који насељавају различите просторе - реке, језера, шуме, поља. Ти духови који су сматрани покровитељима својих локуса дали су живот бројним шумским духовима, воденим, пољским и другим персонажима. У словенским митовима исто тако јасно су изражени ликови који представљају особе са демонским особинама (вештица, мора, чаробњак и др.).

У пограничном положају, између света демона и света људи, у групи митолошких персонажа налази се на првом месту вештица (рус. ведьма), а 
њен назив је етимолошки везан са староруским ве́дь (Фасмер 1996, 1: 285). Универзално за све вештице у општесловенској представи јесте да измузају млеко кравама, да бацају чини на људе; оне лете на људима које су претвориле у животиње, иду на заједничка окупљања одређених дана; могу да се претварају у птице, животиње, разне предмете (точак, сито, стог сена). Вештице су постајале жене услед „судбоносних” околности у које спадају зачеће у одређеном тренутку, рођење у крвавој кошуљици, у последњој фази месеца итд. Жена је могла постати вештица како по рођењу, тако и на основу сопствене воље, склопивши савез са нечистом силом. Код Јужних Словена, код Срба, вештице имају карактеристике које их чине сличним са вампирима: оне пију крв људи и животиња, једу дечја срца. Највише штете наносе одређених дана - На Ђурђевдан, Ивањдан, Благовести.

Код Руса вештице су представљене са седом рашчупаном косом, мршавих руку, огромног модрог носа. Оне лете у ваздуху на жарачу, пајалици, у авану и сл. На своје мрачне послове су обавезно одлазиле кроз димњак и могле су да се претварају у разне животиње, најчешће у свраке, свиње, псе, мачке.

Ђаво (рус. черт) се перципира као носилац апсолутног зла. Појавио се пре хришћанства, да би на веровања о њему јак утицај извршила хришћанска представа о злом духу. Током каснијих преосмишљавања старог митолошког система, када су се многи елементи тог система губили, индивидуалне карактеристике ђавола су нестајале, а сам назив је почео означавати сваки персонаж из домена нечисте силе.

Па ипак, ђаво је сачувао сталне митолошке црте и мотиве, карактеристичне за физиономију тог бића. Он је зло биће, свуда присутно, биће које тумара унаоколо и тражи сваку могућност да наштети човеку. Он нема стални изглед, може попримати сваки облик, укључујући и антропоморфни. Али, пошто не може у целини да понови људски лик, по нечему се разликује од човека: тиме што храма, разрок је, има рошчиће који вире испод шешира, има коњска копита која пажљиво скрива.

Зла бића, која су још у египатској митологији изазивала страх, називали су злим дусима (рус. бес). Из старопаганске терминологије лексема бес је доспела у хришћанску традицију и коришћена је за превод грчке речи демон.

Ђаво може попримити облик животиња, нарочито јарца, овце, јагњета. Ако такав сретне човека на путу, натера га да га носи, а затим изненада нестане уз смех. Ђаволи наговарају човека на самоубиство, наваљују на пијанице, замењују људско дете за своје, богаљасто и прождрљиво. Ђаво присваја себи оно што му је дато неопрезном речју: долази код старца по опанак, јер је овај рекао да га плете ђаволу; једе у кући у којој мајка помиње ђавола док храни децу; пије млеко које је увече остављено без благослова. 


\section{Митолошке номинације у стваралаштву Н. В. Гогоља}

Језичка слика света Н. В. Гогоља представљена је широким спектром митолошких номинација - лексема које означавају персонаже словенске митологије - концепте речи-митологеме.

У језику Гогољевих приповедака откривамо синонимски низ демонолошких номинација, у чијем центру је митолексема черт.

Синоним у пандемонијуму је митономинација дьявол као репрезентант страшне и нечисте зле силе: у речи дьявол звучи мотив продаје човекове душе ђаволу као врховном божанству нечисте силе.

Апсолутни синоними митолексеме чорт у Гогољевим делима су митолошке демонолошке номинације демон, злой (нечистый) дух, дьявол, сатана, черт, нечистая сила, нелегкая; лукавый, враг, искуситель, злой гений, аггел, шейтан; рогатый, хвостатый, косматый; шиш, шишко, шишук, шишига.

Митолексеме које се срећу у Гогољевим делима су негативне конотације.

Феминизирани систем демонолошког континуума репрезентован је на језичком нивоу у Гогољевим делима митолексемама: ведьма, чертовка, яга.

Гогољ је у целини задржао народну традицију виђења ђавола. Украјински пандемонијум може да се структурише у три тачке:

1. Демони кућног огњишта (домовые, стриги);

2. Демони који бораве у природи (водяные, русалки, лесовики);

3. Привиђења (оборотни; чорт, ведьма; колдун; вампир; бес; дьявол; кикимора).

У Гогољевим Вечерима најфреквентније митолексеме су черт и еуфемизми, као и концепт реч-митолексема ведьма, и то: у Сорочинском вашару срећемо следеће митолексеме: дьявол (3 пута), черт (14 пута), сатана (4 пута), лукавый (1 пут); ведьма (2 пута);

У Вечери уочи Ивањдана: черт (7 пута), дьявол (2 пута), лукавый (4 пута), искуситель (1 пут), сатана (1 пут); ведьма (1 пут);

У Зачараном месту: черт (3 пута), сатана (3 пута), дьявол (1 пут);

У Ноћи уочи Божића черт (31 пут), лукавый (1 пут), сатана (3 пута); ведьма (1 пут);

У Мајској ноћи или Дављенищи: черт (9 пута), сатана (6 пута), дьявол (1 пут); ведьма (9 пута);

У Страшној освети: черт (3 пута), дьявол (1 пут), сатана (2 пута); ведьма (2 пута). 
Ми се у овом раду бавимо анализом ових двају концепата речи-митолексема. Остале митолексеме Гогољевог пандемонијума обрађујемо у посебном истраживању, из којег је овај рад издвојен као посебна целина.

\section{Митологема ведьма}

За митологеме је карактеристично одсуство денотата у човековом окружењу, оне су плод људске маште. „У сваком језику постоје знаци са такозваним нултим денотатом, тј. објекти које они означавају су - иреална датост, непостојећи предмет, својеврсни 'мисаони конструкт"' (Уфимцева 1974: 46-47).

Према народном веровању вештица је бацала чини на људе, домаће животиње, биљке, намирнице и др.

Концептуална анализа речи-митологема омогућава откривање базних опозиција које су карактеристичне за руску свест и културу, културне вредности друштва, а истовремено и за опис наивних језичких представа носилаца руског језика, које су настале под утицајем националне перцепције окружења и света.

Садржајни минимум концепта, његове семантичке карактеристике формирају се на бази експлицираних речничких дефиниција речи-митологема у општим и специјализованим речницима и енциклопедијама, на основу колоквијалних и дијалекатских назива, као и на контекстима из публицистичке и уметничке књижевности.

У етимолошком речнику М. Фасмера реч ведьма је везана са старорус. вӗдъ „колдовство”, „ведовство”, „знание” (Фасмер 1996, 1: 285).

Садржајни минимум концепта речи-митологеме ведьма је, у складу са народним веровањем, „женщина - сослужительница дьявола, обладающая сверхъестественными способностями вредить людям и животным». Овај концепт је веома фреквентан у раним приповеткама Н.В.Гогоља. На пример, у Страшној освети: „У отца моего далеко сердце, он не достанет до него. У него сердце из железа выковано. Ему выковала одна ведьма на пекельном огне».

Вештици се, по дефиницији, приписује могућност бацања чини на људе, животиње и биљке. У Мајској ноћи читамо следеће: „Угадала бедная панночка, что мачеха ее ведьма и что она ей перерубила руку ... Тогда только зарыдала панночка, закрывши руками белое лицо свое: „Погубил ты, батьку, родную дочку свою! Погубила ведьма грешную душу твою!...” ... „Парубок, найди мне мою мачеху! Она страшная ведьма: мне нет от неё покою на белом свете. Она мучила меня, заставляла работать, как простую мужичку. Посмотри на лицо: она вывела румянец своими нечистыми чарами с щек моих ...” 
Постоји веровање о томе да вештице ноћу измузају краве. У Ноћи уочи Божића пастир види сопственим очима како то вештица ради: „Он (пастух Тымиш) не преминул рассказать, как летом перед самою Петровкою, когда он лег спать в хлеву, подмостивши под голову солому, видел собственными глазами, что ведьма с распущенною косою, в одной рубашке, начала доить коров, а он не мог пошевельнуться, так был околдован; подоивши коров, она пришла к нему и помазала его губы чем-то таким гадким, что он плевал после того целый день”.

Вештица се понекад замишљала као стара неугледна жена седе рашчупане косе, повијеног носа, чворноватих руку, понекад је била грбава или хрома (Бељакова 1995: 150-152). „Не бесись, не бесись, старая чертовка!” - проговорил Басаврюк, приправив таким словцом, что добрый человек и уши бы заткнул. Глядь, вместо кошки старуха с лицом, сморщившимся, как печеное яблоко, вся согнутая в дугу; нос с подбородком словно щипцы, которыми щелкают орехи. „Славная красавица!” - подумал Петро, и мурашки пошли по спине его. Ведьма вырвала у него цветок из рук, наклонилась и что-то долго шептала над ним, вспрыскивая какою-то водою. (Гогољ, Вече уочи Ивањдана).

Речници руског језика бележе и значење ове лексеме као о „злой, сварливой ... женщине" (БТС, 2: 119). - Вишь, как ругается.! - сказал парубок, вытаращив на неё глаза, как будто озадаченный таким сильным залпом неожиданных приветствий , - и язык у нее, у столетней ведьмы, не заболит выговорить эти слова" (Гогољ, Сорочински сајам).

Врло често је у речи-митологеми ведьма садржана негативна конотација у опису жене у вези са њеним изгледом, а сама реч има стилску карактеристику погрдно (рус. бранное). С тим што синтагма „старая ведьма” може да се употреби за жену било ког узраста. „А вот к кому ходит дьяк!” - сказала баба с фиолетовым носом, указывая на ткачиху. „Так это ты, сука, - сказала дьячиха, подступая к ткачихе, - так это ты, ведьма, напускаешь ему туман и поишь нечистым зельем, чтобы ходил к тебе”. „Отвяжись от меня, сатана!” - говорила пятясь ткачиха. „Вишь, проклятая ведьма, чтоб ты не дождала детей своих видеть, негодная! Тьфу!” - тут дьячиха плюнула прямо в глаза ткачихе (Гогољ, Ноћ уочи Божића).

Један од стандардних атрибута који се асоцира са вештицом јесте метла: „Тут через трубу одной хаты клубами повалил дым и пошел тучею по небу, и, вместе с дымом, поднялась ведьма верхом на метле" (Гоголь, Ноћ уочи Божића).

На основу синтагматских веза откривамо вештичине функције, као и асоцијације и семантику које проистичу из тог лика: вештица је зла, она опчини човека, стара вештица, вештица је унесрећила душу, страшна, проклета вештица. 
На нивоу парадигматике митологема ведьма је повезана са лексемама русалка, кикимора, леший, домовой, што потврђују бројне контекстуалне употребе ових лексема.

Дакле, базни концепт ведьма има следеће параметре: митологема ведьма је према унутрашњој форми везана са старорус. вӗдъ „,колдовство”, „ведовство”, „знание” и има исти корен са глаголом вӗдать (ст.рус. вецдати); садржајни минимум ове лексеме је - ,жена која поседује посебна знања и чаробњачке способности"; простор на коме борави је или шума, или је међу људима; према спољним карактеристикама је понекад стара и безлика, има физичке недостатке и реп; функција и радње које обавља - баца чини на људе, стоку, биљке, изазива елементарне непогоде, преобраћа се у животиње и птице, јаше на метли, лети у врзино коло; према човеку може бити опасна или корисна.

\section{Реч-митологема чёрт (чорт)}

Најфреквентнија лексема од свих митологема у раним Гогољевим приповеткама је концепт реч-митологема чёрт (чорт).

Чёрт (чорт) - Ђаво се перципира као носилац апсолутног зла. Појавио се пре хришћанства, да би на веровања о њему јак утицај извршила хришћанска представа о злом духу. Током каснијих преосмишљавања старог митолошког система, када су се многи елементи тог система губили, индивидуалне карактеристике ђавола су нестајале, а сам назив је почео означавати сваки персонаж из домена нечисте силе.

Па ипак, ђаво је сачувао сталне митолошке црте и мотиве, карактеристичне за физиономију тог бића. Он је зло биће, свуда присутно, биће које тумара унаоколо и тражи сваку могућност да наштети човеку. Он нема стални изглед, може попримати сваки облик, укључујући и антропоморфни. Али, пошто не може у целини да понови људски лик, по нечему се разликује од човека: тиме што храма, разрок је, има рошчиће који вире испод шешира, има коњска копита која пажљиво скрива.

Зла бића, која су још у египатској митологији изазивала страх, називали су злим дусима (рус. бес). Из старопаганске терминологије лексема бес је доспела у хришћанску традицију и коришћена је за превод грчке речи демон.

Ђаво може попримити облик животиња, нарочито јарца, овце, јагњета. Ако такав сретне човека на путу, натера га да га носи, а затим изненада нестане уз смех. Ђаволи наговарају човека на самоубиство, наваљују на пијанице, замењују људско дете за своје, богаљасто и прождрљиво. Ђаво присваја себи оно што му је дато неопрезном речју: долази код старца по опанак, јер је овај рекао да га плете ђаволу; једе у кући у којој мајка помиње ђавола док храни децу; пије млеко које је увече остављено без благослова. 
На основу сазнања из фолклора Гогољ поима дубинске митолошке изворе који говоре о самосвести и самобитности словенског живља. За Гогољеве персонаже мит је непосредно уткан у садржај живота. И чак персонажи доњег света (ђаволи, вешци, вештице) нису мистификована, већ сасвим обична, свакодневна бића. Гогољеви ђаволи једу и пију, спавају, заљубљују се итд.

Међу бићима доње митологије код Гогоља централно место заузима ђаво. Ђаво је код Гогоља више комичан него страшан. У Сорочинском вашару читамо: „Как же могло статься, чтобы черта выгнали из пекла?”- удивляется Черевик. - Что ж делать, кум? Выгнали да и выгнали, как собаку мужик выгоняет из хаты. Может быть на него нашла блажь сделать каакое-нибудь доброе дело, ну и указали на двери".

У раним Гогољевим приповеткама могу да се издвоје два основна типа „нечастивог”. Први је представљен персонажима који оваплоћују „непријатеља људског рода", и такви су они којима се приписују митолошке карактеристике лексема черт и бес. То је ђаво из Сорочинског вамара, затим из Ноћи уочи Божића, Басаврјук и шумски зао дух из Вечери уочи Ивањдана.

Гогољ понекад трансформише ђавола, називајући га Немцем у Ноћи уочи Божића. Напомиње да под Немцем подразумева свакога ко је из „туђе земље”. Дакле, ђаво је „спереди совершенно немец” - ђаво из Ноћи уочи Божића. То му говори Вакула: „А вот каким голосом запел, немец проклятый”.

Други тип чине нечастиви нижи по рангу, или пак људи који су потпали под утицај ђавола или су продали ђаволу душу. То је Петро, госпођичин отац или Пацук из Ноћи уочи Божића. Сви персонажи доњег света имају типолошки исте карактеристике: мрк, непријатељски поглед, очи из којих понекад избија огањ, специфичан изглед, са врло мало говора.

Гогољ се различито односи према ђаволу, додељујући му следеће функционалне карактеристике.

1. Један од њих је ђаво-кушач. Предмет кушања најчешће је новац у разним облицима, власт, могућност изазивања узвраћене љубави итд. У Вечери уочи Ивањдана Басаврјук успева да потчини себи момка („парубка”) Петра обећањем богатства и љубави Пидоркине. Новац који ђаво даје увек је лажан, илузоран и служи као својеврсно „замазивање очију”.

Заузврат нечастиви тражи или људску душу или извршавање задатака који неповратно уништавају човека. Тако, пратећи ђавољу вољу, Петро убија невино дете.

2. Други модалитет Гогољевог ђавола јесте заводник. Извори кажу да је та функција нечастивог из периода паганства и да су касније додати хришћански утицаји. Однос ђавола према жени манифестује куртоазне манире који нису карактеристични за свакодневни живот обичног света. Сетимо се како се страс- 
твено удвара ђаво кицош вештици Солохи у Ноћи уочи Божића. „Черт между тем не на шутку разнежился у Солохи, целовал ее руку с такими ужимками, как заседатель у поповны, брался за сердце, охал ...”

3. Ђаво-обешењак је такође везан за пагански период и представу о постојању врачева, и он стално провоцира човека несташлуцима и ситним пакостима. Гогољев ђаво често доводи човека у заблуду, вара га и обмањује, вуче га за нос. Такву шалу је нечастиви приредио персонажу Зачараног места, исмејавши ђавола. ,Захочет обморочить дьявольская сила, ей-богу обморочит” - тако каже јунак ове приче кога су полили помијама. А смех нечисте силе, ђавола је симболичан, он представља начин за психолошко понижавање и потчињавање, он је жеља да се још једном истакне своја снага и моћ. Међутим, несташлуци нечастивог не успевају увек. Желећи да напакости ковачу Вакули и свим добрим хришћанима, нечастиви одлучује да украде месец. „... Хитрый черт не оставил своих проказ. Подбежавши, вдруг схватил он обеими руками месяц, кривляясь и дуя перекидывал его из одной руки в другую, как мужик, доставший голыми руками огонь для своей люльки; наконец, поспешно спрятал в карман”. Међутим, не само да није успео његов покушај с месецом, већ га је Вакула и истукао.

4. Следећи тип Гогољевог ђавола био би ђаво који воли да се проводи и пије. Гогољев ђаво воли ракију. Та карактеристика зближава нечастивог са паганским архетипом, према којем је ђаво одувек повезан са алкохолом. Представљен је кроз лик Басаврјука у Вечери уочи Ивањдана, он је „дьявол в человеческом образе”, лумпује, пије, „деньги сыплются, водка - как вода". Сусрет са ђаволом је често у биртији, тамо се пије и приређује богата гозба.

5. И најзад, још једна функција Гогољевог персонажа - то је ђаво који игра карте. Игра карата ђавола са човеком или његовим окружењем је својеврстан двобој у коме је улог људски живот. У овом случају у борби са ђаволом понекад не помаже ни крст. Отац Атанасије из Вечери уочи Ивањдана никако не може да савлада ђавола Басаврјука. „И даром, что отец Афанасий ходил по всему селу со святой водою и гонял черта кропилом по улицам, ... кто-то, как только вечер, стучит в крышу и царапается по стене".

Једино, право оруђе у борби против ђавола је икона, и то она без икаквих украса. Вешца из Страшне освете истерују иконом, на којој „не гори ни сребро, ни злато".

Језгро овог концепта је концептуална особина „злой дух, воплощение зла", пошто је ова смисаона компонента постојана и показује садржај концепта. У лексикографским изворима се експлицирају следећи мотиви и сижеи о ђаволу: чёрт пугает, подталкивает к самоубийству, черти устраивают разгром в доме, черт подменяет ребенка чуркой (поленом), черт награждает золотом, которое превращается в угли, черт забирает себе отданное ему неосторожным 
словом итд. Базни слој концепта представља особина „нечистая сила”. На периферији концепта су особине „правитель царства мертвых” и „покровитель домашнего скота".

Дакле, базни концепт черт има унутрашњу форму „владар царства мртвих, проклети дух”; садржајни минимум је „зао дух, нечиста сила”; место боравка му је „онај свет”; према спољној карактеристици то је човеколико биће са репом и коњским копитама или кокошјим ногама; има способност преобраћања; понекад нема конкретан облик. Према функцијама и радњама - наноси штету људима, одвлачи их у шуму, наводи их да залутају, доводи их до смрти, руга се човеку. Непријатељски је расположен према сваком живом бићу.

Идиолект Н. В. Гогоља карактерише употреба номинација које означавају митолошка бића. Митолексеме у пишчевој језичкој слици света одређују метатекст перцепције језичког функционисања и маркирају стилски потенцијал Гогољевих дела.

ГРАЂА

Н. В. Гоголь, Собрание сочинений в четырех томах, Библиотека отечественной классики, Москва: Правда, 1968.

\section{ЛИТЕРАТУРА}

Абрамов 1994: Н. Абрамов, Словарь русских синонимов и сходных по смыслу выражений, Издание 5-е, исправленное и дополненное, Москва: Руссике словари.'

Александрова 1975: 3.Е. Александрова, Словарь синонимов русского языка, Издание 4-е, Москва: Русский язык.

БАС 1948-1965: Словарь современного русског языка, Академия Наук СССР, Институт языкознания, том шестой, Издательство Академии наук СССР: Москва-Ленинград.

Бељакова 1995: Г.С. Белякова, Славянская мифология (СМ), Москва: Просвещение.

БСЭ 1974: Большая советская энциклопедия, 3-е издание, Советская энциклопедия: Москва.

Виноградов 1994: В.В. Виноградов, История слов, Москва: Толк. 
Виноградов 1936: В.В. Виноградов, Язык Гоголя // Н.В. Гоголь, Материалы и исследования, Москва-Ленинград, т. 1-2.

Горбачевич 1996: К.С. Горбачевич, Русский синонимический словарь, СанктПетербург, ИЛИ РАН.

Кајсаров и др. 1993: А.С. Кайсаров, Г. А. Глинка, Б. А. Рыбаков, Мифы древних славян, Саратов: Надежда.

Кулишић и др. 1998: Ш. Кулишић, П. Ж. Петровић, Н. Пантелић, Српски митолошки речник, Београд: Нолит.

Левкијевска 1996: Е.Е. Левкиевская, Низшая мифология славян, у: Очерк истории культуры славян, РАН, Институт славяноведения и балканистики, Москва: Индрик.

Ман 1988: Ю.В. Манн, Поэтика Гоголя, издание 2-е, дополненное, Москва: Художественная литература.

МНМ 1980: Мифы народов мира, в двух томах, Советская энциклопедия: Москва.

Нидерле 2000: Л. Нидерле, Славянские древности, Перевод с чешского, Москва: Алетейа, 2000.

Речник руског језика 1984: Словарь русского языка в четырех томах, $\mathrm{AH}$ СССР, Институт русского языка, Москва: Русский язык, т. 4.

Речник синонима РАН 1971: Словарь синонимов русского языка в двух томах, АН СССР, Ленинград: Наука.

Речник САНУ 1984: Речник српскохрватског књижевног и народног језика, књига XII, Институт за српскохрватски језик: Београд, 1984.

Рибаков 1988: Б.А. Рыбаков, Язычество древней Руси, Наука: Москва.

Рибаков 1994: Б.А. Рыбаков, Язычество древних славян, Наука: Москва.

СУ 1996: СУ (Толковый словарь русского языка в четырёх томах), Москва: TEPPA.

Срезњевски 1989: И.И. Срезневский, Словарь древнерусского языка, репринтное издание, том второй, часть первая, Москва: Книга.

Степанов 2001: Ю.С. Степанов, Константы: Словарь русской культурь, Издание 2-е, исправленное и дополненное, Москва: Академический проект.

Толстој 1995: Н.И. Толстой, Язык и народная культура, Очерки по славянской мифологии и этнолингвистике, РАН, Институт славяноведения и балканистики, Москва: Индрик. 
Толстој 1996: Н.И. Толстой, Религиозные верования древних славян. Язычество древних славян, у: Очерк истории культуры славян, РАН, Институт славяноведения и балканистики, Москва: Индрик.

Трубачов 1976: Этимологические исследования и лексическая семантика // Принципы и методы семантических исследований, Москва: Наука.

Уфимцева 1974: А.А.Уфимцева, Типь словесных знаков, Москва: Наука.

Фасмер 1996: Макс Фасмер, Этимологический словарь русского языка, В четырёх томах, Санкт-Петербург: Азбука, Терра.

Черних 1993: П.Я. Черных, Историко-этимологический словарь современного русского языка, Т. 1-2, Москва: Русский язык.

\section{МИФОЛОГЕМЫ В ТВОРЧЕСТВЕ Н.В. ГОГОЛЯ}

\section{Резюме}

Данная статья посвящена исследованию мифологем восточнославянской мифологии в раннем творчестве Н.В. Гоголя Вечера на хуторе близ Диканьки. Упомянутые мифологемы принадлежат к сфере „низшей мифологии”. В соответствии с целью исследования определен характер терминов миф, мифология; выявлены мифологемы в повестях Вечеров и проанализированы концепты слова-мифологемы ведьма и черт методом мифологического архетипа.

Милена Б. Мароевич 